\title{
Kecerdasan Emosional Memoderasi Pengaruh Tekanan Peran terhadap Kejenuhan Kerja Auditor Pada KAP Provinsi Bali
}

\author{
Ni Putu Yulia Antari ${ }^{1}$ \\ Fakultas Ekonomi dan Bisnis \\ Universitas Udayana, Indonesia
}

\author{
Ketut Alit Suardana ${ }^{2}$ \\ Fakultas Ekonomi dan Bisnis \\ Universitas Udayana, Indonesia
}

\section{ABSTRAK}

Tujuan dari penelitian ini adalah menganalisis kecerdasan emosional memoderasi pengaruh tekanan peran terhadap kejenuhan kerja auditor pada Kantor Akuntan Publik Provinsi Bali. Penelitian ini dilakukan di seluruh KAP Provinsi Bali sebanyak sembilan kantor yang terdapat pada Wilayah Bali tahun 2019 dengan menjadikan auditor sebanyak 48 orang sebagai sampel dengan metode sample jenuh. Pengumpulan data dilakukan dengan menyebarkan kuesioner, di uji melalui teknik moderasi regresi analisis (MRA). Berdasarkan hasil analisis, variabel tekanan peran berpengaruh positif signifikan terhadap kejenuhan kerja auditor pada KAP di Provinsi Bali. Kecerdasan emosional memoderasi pengaruh tekanan peran berpengaruh positif signifikan terhadap kejenuhan kerja auditor pada KAP di Provinsi Bali.
\end{abstract}

Surel : yuliaantari37@gmail.com

Kata Kunci: Tekanan Peran; Kecerdasan Emosional; Kejenuhan Kerja.

\section{Emotional Intelligence Moderates the Influence of Role Pressure on the Saturation of Auditor's Work at KAP Bali Province}

\begin{abstract}
The purpose of this study is to analyze emotional intelligence moderating the influence of role pressure on the saturation of auditor performance in Bali Provincial Public Accountant Firm. This research was conducted in all Public Accountant Firm offices in Bali Province as many as nine offices in the Bali Region in 2019 by making 48 auditors as samples with the saturated sample method. Data collection is done by distributing questionnaires, tested through regression analysis moderation techniques. Based on the results of the analysis, the role pressure variable has a significant positive effect on the saturation of the auditor's performance at Public Accountant Firm in Bali Province. Emotional intelligence moderates the influence of role pressure significantly positive effect on the saturation of the auditor's performance on Public Accountant Firm in the province of Bali.
\end{abstract}

Keywords: Role Pressure; Emotional Intelligence; Work Saturation.

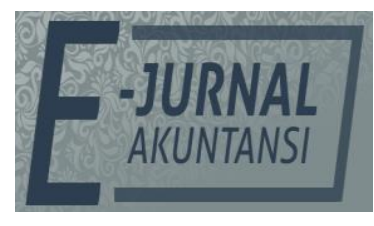

e-ISSN 2302-8556

Vol. 31 No. 1

Denpasar, Januari 2021 Hal. 197-207

DOI:

10.24843/EJA.2021.v31.i01.p15

PENGUTIPAN:

Antari, N.P.Y., \& Sudana, K.A. (2021). Kecerdasan Emosional Memoderasi Pengaruh Tekanan Peran terhadap Kejenuhan Kerja Auditor Pada KAP Provinsi Bali. E-Jurnal Akuntansi, 31(1), 197-207

RIWAYAT ARTIKEL:

Artikel Masuk:

20 Desember 2019 Artikel Diterima: 13 Desember 2020

Artikel dapat diakses : https://ojs.unud.ac.id/index.php/Akuntansi/index 


\section{PENDAHULUAN}

Profesi seorang akuntan publik memegang peranan sosial yang sangat penting untuk memberikan pelayanan jasa kepada masyarakat. Peran tersebut berhubungan dengan tugas dan tanggung jawab yang diemban oleh akuntan publik (Shukla \& Srivastava, 2016). Tugas dari seorang akuntan publik adalah memeriksa, mereviu dan memberikan opini mengenai kualitas dari laporan keuangan atas suatu entitas, berdasarkan standar yang telah ditentukan oleh Ikatan Akuntasi Indonesia (Dikdik, 2008). Banyak masalah yang dapat ditimbulkan dari kesalahan yang dilakukan oleh auditor dalam melaksanakan audit, yang diakibatkan dari tekanan pekerjaan yang tinggi, menimbulkan tekanan peran yang dialami oleh auditor sehingga auditor memiliki kejenuhan dalam bekerja dan dianggap tidak mampu menyelesaikan pekerjaannya (Gbenro, 2014).

Mengingat pentingnya peran pengawasan dalam suatu perusahaan, maka auditor independen menjadi satu-satunya unit kerja yang paling tepat untuk melaksanakannya. Karena itu, peran auditor independen yang selama ini selalu berkaitan dengan urusan pengendalian dan pengawasan harus sudah bergeser dari sekedar terkesan sebagai pengawas perusahaan menjadi unit yang mampu berperan dalam pencegahan sekaligus pendeteksian perilaku yang menyimpang di dalam perusahaan seperti kecurangan, manipulasi data yang menyebabkan kerugian bagi perusahaan (Rahayu \& Widhiyani, 2020). Jasa profesi akuntan publik harus dapat mempertanggungjawabkan hasil temuan audit kepada pihak-pihak yang berkepentingan dengan pertanggungjawaban yang diberikan dari hasil temuannya (Liman \& Merkusiwati, 2017). Profesi di bidang akuntansi khususnya auditor, merupakan profesi yang memiliki tekanan peran yang tinggi. Auditor harus melakukan pembatasan dalam menjalankan tugasnya, yaitu auditor harus berkomunikasi dengan banyak orang yang memiliki kebutuhan dan harapan yang berbeda-beda, untuk mendapatkan informasi yang berguna dalam pengambilan keputusan. Individu yang berada pada situasi di mana mereka diberikan batas dalam melakukan pekerjaannya sangat berpotensi mengalami tekanan peran. Auditor adalah profesi yang berpotensi mengalami stres karena banyaknya tekanan peran dalam pekerjaannya sehingga memiliki kejenuhan dalam bekerja (Wiryathi et al., 2014).

Kejenuhan kerja adalah perilaku negatif pada kinerja. Kejenuhan merupakan representasi dari sindrom stres secara psikologis, yang menunjukkan respon negatif sebagai hasil dari tekanan-tekanan pekerjaan. Kejenuhan kerja auditor dalam pelaksanaan program audit merupakan faktor penting yang berpengaruh terhadap hasil temuan audit (Dikdik, 2008). Kejenuhan kerja sebagai sindrom psikologis dari kelelahan emosional, depersonalisasi, dan penurunan prestasi kerja, yang muncul di antara individu-individu yang bekerja dengan orang lain (Budiasih, 2017). Kejenuhan kerja adalah setiap tindakan negatif dalam pelaksanaan audit yang dapat menurunkan hasil temuan audit secara langsung maupun tidak langsung. Penyebab kejenuhan kerja yang dialami adalah terperangkap dalam situasi yang tidak dapat lepas dari tekanan peran dalam pekerjaan (Aggarwal, 2017). Kejenuhan kerja dapat terjadi akibat dari kumulatif tekanan peran secara terus-menerus dalam jangka panjang yang dialami oleh individu dalam berbagai tingkatan dan kombinasi (Rizkia, 
2015). Tekanan peran ini mempunyai akibat yang umumnya negatif seperti menurunnya kualitas hasil kerja, rendahnya loyalitas, dan terjadinya perilaku kejenuhan kerja pada auditor (Sari \& Suryanawa, 2016). Dikdik (2008) menyatakan hal yang sama yakni tekanan peran secara positif berpengaruh terhadap perilaku kejenuhan kerja auditor, dimana tekanan peran memiliki pengaruh terhadap perilaku kejenuhan kerja auditor. Ermayanti (2017) membuktikan bahwa terdapat pengaruh positif tekanan peran terhadap perilaku kejenuhan kerja auditor.

Tekanan peran dapat dikategorikan kedalam dua jenis yaitu eustress yang berdampak positif bagi kehidupan manusia dan distress yang memiliki dampak negatif (Sari \& Suryanawa, 2016). Tekanan peran pada tingkat tertentu justru dapat memotivasi seseorang untuk meningkatkan kinerja dan menyelesaikan pekerjaannya. Namun tingkat tekanan peran yang berlebihan dapat berdampak negatif yang dapat menimbulkan penurunan kinerja, serta dapat menimbulkan depresi dan kegelisahan (Wiryathi et al., 2014). Kejenuhan kerja sebagai perilaku yang menyimpang tentu saja dipengaruhi oleh beberapa faktor diluar tekanan peran, antara lain adalah kecerdasan emosional (Samaei et al., 2017). Kecerdasan emosional menuntut diri untuk belajar mengakui dan menghargai perasaan diri sendiri dan orang lain serta untuk menanggapinya dengan tepat, menerapkan dengan efektif energi emosi dalam kehidupan dan pekerjaan sehari-hari (Akintayo, 2010). Pada kenyataannya perlu diakui bahwa kecerdasan emosional memiliki peran yang sangat penting untuk mencapai kesuksesan bagi seorang auditor di tempat kerja dan berkomunikasi di lingkungan masyarakat (Murtiasri, 2006).

Penelitian Samaei et al. (2017). menyatakan pengaruh tekanan peran secara positif terhadap perilaku kejenuhan kerja auditor secara moderasi dapat diperlemah oleh kecerdasan emosional. Kecerdasan emosional memoderasi dengan memperlemah hubungan tekanan peran terhadap kejenuhan kerja auditor (Wiryathi et al., 2014). Karyawan yang memiliki kecerdasan emosional yang tinggi bisa mengontrol dan mengelola tekanan peran dengan baik dalam arti mampu memperkuat atau memperlemah tekanan peran yang dialaminya. Kecerdasan emosional berpengaruh pada perilaku tiap individu dalam mengatasi permasalahan yang terjadi dalam diri orang tersebut, termasuk dalam lingkungan kerjanya, dengan memiliki kecerdasan emosi seseorang dapat memotivasi diri, tidak mudah frustasi, dan yang terpenting adalah mampu mengendalikan tekanan peran (Avionela \& Fauziah, 2016). Kemampuan ini saling melengkapi dan berbeda dengan kemampuan akademik murni, yaitu kemampuan kognitif murni yang diukur dengan Intelektul Quotien (Erbil, 2016).

Teori peran (role theory) dikemukakan oleh Kevereski et al. (2016) digunakan sebagai teori yang melandasi pembahasan mengenai masalah tekanan peran seorang auditor. Teori peran merupakan penekanan sifat individual sebagai pelaku sosial yang mempelajari perilaku yang sesuai dengan posisi yang ditempati di masyarakat. Peran yang dimainkan oleh seseorang dapat menjadi faktor penyebab adanya tekanan kerja karena seseorang dalam kehidupannya tidak hanya memainkan satu peran (Vlachou, 2016) Tekanan peran dapat terjadi jika individu sulit menginterpretasikan harapan-harapan tersebut, terdapat ketidakjelasan harapan atas peran yang dijalankannya, atau terdapat konflik 
antara harapan atas peran yang satu dengan peran lainnya (Santos, 2016). Maka hipotesis pertama yang dapat dirumuskan adalah sebagai berikut.

$\mathrm{H}_{1}$ : Tekanan peran berpengaruh positif terhadap kejenuhan kerja auditor.

Beberapa penelitian seperti Liman \& Merkusiwati (2017) menyatakan kecerdasan emosional memoderasi dengan memperlemah hubungan tekanan peran terhadap kejenuhan kerja auditor. Wiryathi et al. (2014) membuktikan bahwa kecerdasan emosional secara moderasi dapat mengurangi terjadinya tekanan peran sehingga mampu menurunkan kejenuhan kerja auditor. Avionela \& Fauziah (2016) kejenuhan kerja auditor yang dipengaruhi oleh tekanan peran dapat dihindari dengan moderasi variabel kecerdasan emosional. Samaei et al. (2017) menyatakan hal yang sama pengaruh tekanan peran secara positif terhadap kejenuhan kerja auditor secara moderasi dapat diperlemah oleh kecerdasan emosional. Hipotesis kedua dapat dirumuskan sebagai berikut.

$\mathrm{H}_{2}$ : Kecerdasan emosional memoderasi pengaruh tekanan peran terhadap kejenuhan kerja auditor.

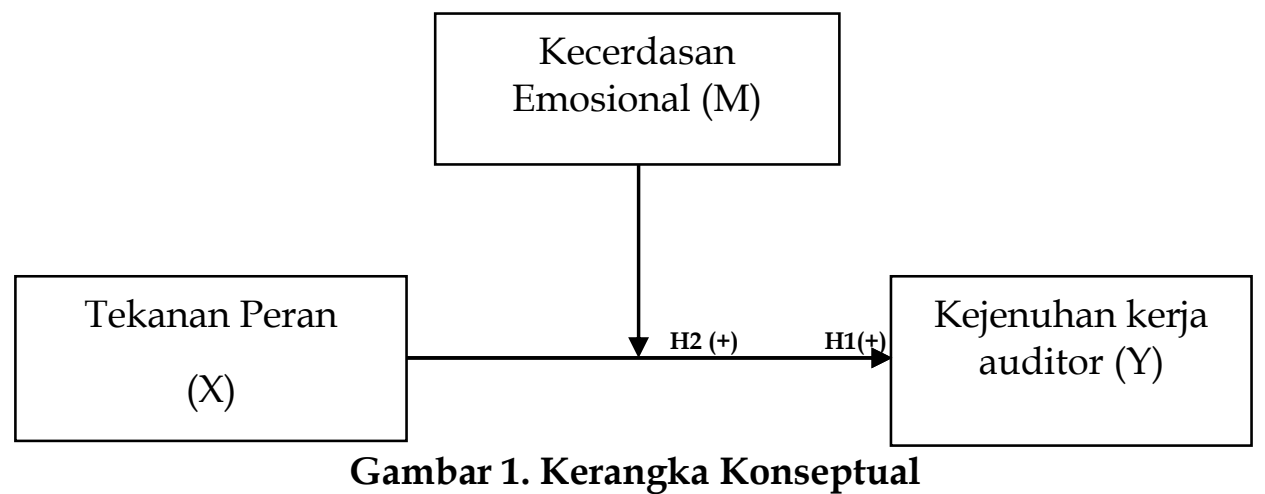

Sumber: Data Penelitian, 2020

\section{METODE PENELITIAN}

Berdasarkan permasalahan yang diteliti, penelitian ini digolongkan pada penelitian asosiatif (hubungan), yaitu penelitian yang bertujuan untuk mengetahui hubungan dari variabel atau lebih (Sugiyono, 2017). Objek penelitian dalam penelitian ini adalah peran kecerdasan emosional memoderasi pengaruh tekanan peran terhadap kejenuhan kerja auditor. Variabel yang akan dianalisis adalah variabel bebas $(X)$ yang dalam penelitian ini adalah tekanan peran $(X)$, variabel moderasi $(\mathrm{M})$ yang dalam penelitian ini adalah kecerdasan emosional, dan variabel terikat $(Y)$ yang dalam penelitian ini adalah kejenuhan kerja auditor. Jenis data kuantitatif dan kualitatif yang dipergunakan seperti berupa angkaangka atau data yang dapat dihitung seperti data tanggapan responden terhadap kuesioner yang diberikan, jumlah sampel responden. Sumber data primer dan sekunder yang dipergunakan seperti observasi dan pemberian kuesioner kepada responden, sejarah berdirinya perusahaan, dan jumlah pelanggan. Populasi dalam penelitian ini adalah seluruh auditor yang bekerja pada Kantor Akuntan Publik di Provinsi Bali yang berjumlah sebanyak 48 orang.

Jumlah sampel dalam penelitian ini adalah sebanyak 48 responden yaitu keseluruhan auditor yang bekerja di Kantor Akuntan Publik di Provinsi Bali 
dengan menggunakan metode sampling jenuh, dimana teknik penentuan sampel ini bila semua anggota populasi digunakan sebagai sampel.

Uji validitas menyatakan sebuah instrumen dikatakan valid jika item yang mempunyai korelasi positif dengan kriterum (skor total) serta korelasi tinggi menunjukkan bahwa item tersebut mempunyai validitas yang tinggi pula. Syarat minimum untuk dianggap memenuhi syarat adalah kalau $r=0,3^{\prime \prime}$. Uji reabilitas ditunjukkan dengan angka indeks yang konsistensi suatu alat ukur dalam mengukur gejala yang sama. Uji reabilitas mampu menunjukan sejauh mana instrument dapat dipercaya dan diharapkan. Nilai suatu instrumen dikatakan reliabel bila nilai Alpha Cronbach $\geq 0,6$.

Teknik perhitungan dan analisis data menggunakan moderating regression analysis. Moderating regression analysis dinyatakan dalam bentuk regresi berganda dengan persamaan mirip regressi polynomial yang menggambarkan pengaruh nonlinier (Ghozali, 2016) yang dinyatakan dalam bentuk model persamaan sebagai berikut.

$$
Y=\alpha+\beta_{1} X+\beta_{2}(X M)+\varepsilon
$$

Uji kelayakan model bertujuan untuk menguji apakah model yang digunakan dalam penelitian ini layak untuk digunakan atau tidak. Langkahlangkah dalam uji kelayakan model (Uji F) adalah sebagai berikut : menentukan taraf nyata sebesar $\leq 0,05$. Menentukan besarnya $p$-value yang diperoleh dari hasil pengujian dengan program SPSS. Uji signifikansi parameter individual digunakan untuk menguji signifikansi koefisien regresi atau pengaruh secara parsial dari variabel bebas terhadap variabel terikat. Masing-masing hasil perhitungan setiap variabel ini kemudian dibandingkan nilai signifikansi yang diperoleh dengan menggunakan taraf nyata $\leq$ 0,05 (Ghozali, 2016).

\section{HASIL DAN PEMBAHASAN}

Pengujian awal dilakukan dengan melakukan uji instrumen penelitian yang berupa kuesioner dengan uji validitas dan reliabilitas. Masing-masing disajikan dalam Tabel 1, dan Tabel 2.

\section{Tabel 1. Rangkuman Hasil Uji Validitas}

\begin{tabular}{lcc}
\hline Variabel & Instrumen & Pearson Correlation \\
\hline \multirow{4}{*}{ Tekanan peran $(\mathrm{X})$} & $\mathrm{X}_{1.1}$ & 0,808 \\
& $\mathrm{X}_{1.2}$ & 0,589 \\
& $\mathrm{X}_{1.3}$ & 0,615 \\
& $\mathrm{X}_{1.4}$ & 0,730 \\
& $\mathrm{X}_{1.5}$ & 0,618 \\
& $\mathrm{M}_{1.1}$ & 0,537 \\
Kecerdasan emosional $(\mathrm{M})$ & $\mathrm{M}_{1.2}$ & 0,578 \\
& $\mathrm{M}_{1.3}$ & 0,763 \\
& $\mathrm{M}_{1.4}$ & 0,818 \\
& $\mathrm{M}_{1.5}$ & 0,650 \\
Kejenuhan kerja $(\mathrm{Y})$ & $\mathrm{Y}_{1}$ & 0,679 \\
& $\mathrm{Y}_{2}$ & 0,791 \\
& $\mathrm{Y}_{3}$ & 0,828 \\
\hline
\end{tabular}

Sumber: Data Penelitian, 2020 
Dapat dilihat bahwa masing-masing indikator variabel memiliki nilai person correlation lebih besar dari 0,30, maka ini berarti butir kuesioner yang digunakan layak valid dan dapat digunakan.

Tabel 2. Hasil Uji Reliabilitas

\begin{tabular}{ll}
\hline Variabel & Cronbach's Alpha \\
\hline Tekanan peran $(X)$ & 0,699 \\
Kecerdasan emosional $(\mathrm{M})$ & 0,688 \\
Kejenuhan kerja $(\mathrm{Y})$ & 0,652 \\
\hline
\end{tabular}

Sumber: Data Penelitian, 2020

Dapat dilihat bahwa nilai Cronbach's Alpha untuk masing-masing variabel $>0,6$, ini berarti alat ukur tersebut akan memberikan hasil yang konsisten apabila alat ukur tesebut digunakan kembali untuk meneliti obyek yang sama.

Untuk mengukur nilai sentral dari distribusi data dapat dilakukan dengan pengukuran rata-rata (mean) sedangkan standar deviasi merupakan perbedaan nilai data yang diteliti dengan nilai rata-ratanya.

Tabel 3. Hasil Statistik Deskriptif

\begin{tabular}{llllll}
\hline Variabel & $\mathrm{N}$ & Min. & Max. & Mean & Std. Deviasi \\
\hline Tekanan peran & 48 & 2,20 & 4,60 & 3,6625 & 0,62044 \\
Kecerdasan emosional & 48 & 2,00 & 4,80 & 3,7375 & 0,69669 \\
Kecerdasan emosional-tekanan & 48 & 4,40 & 21,12 & 13,9808 & 4,10941 \\
peran & 48 & 2,67 & 4,67 & 3,8200 & 0,54079 \\
Kejenuhan kerja & & & & &
\end{tabular}

Sumber: Data Penelitian, 2020

Dapat dilihat bahwa variabel tekanan peran $(X)$ memiliki nilai minimum sebesar 2,20 yang berarti rata-rata penurunan nilai tekanan peran terhadap kejenuhan kerja sebesar 2,20 persen, nilai maksimum sebesar 4,60 yang berarti rata-rata peningkatan nilai tekanan peran terhadap kejenuhan kerja sebesar 4,60 persen, mean sebesar 3,6625 yang berarti rata-rata kontribusi pengaruh variabel tekanan peran terhadap kejenuhan kerja sebesar 3,6625 persen, dan standar deviasi sebesar 0,62044 . Ini berarti bahwa terjadi perbedaan tekanan peran yang diteliti terhadap nilai rata-ratanya sebesar 0,62044 persen.

Variabel kecerdasan emosional (M) memiliki nilai minimum sebesar 2,00 yang berarti rata-rata penurunan nilai kecerdasan emosional terhadap kejenuhan kerja sebesar 2,00 persen, nilai maksimum sebesar 4,80 yang berarti rata-rata peningkatan nilai kecerdasan emosional terhadap kejenuhan kerja sebesar 4,80 persen, mean sebesar 3,7375 yang berarti rata-rata kontribusi pengaruh variabel kecerdasan emosional terhadap kejenuhan kerja sebesar 3,7375 persen, dan standar deviasi sebesar 0,69669. Ini berarti bahwa terjadi perbedaan nilai kecerdasan emosional yang diteliti terhadap nilai rata-ratanya sebesar 0,69669.

Variabel kecerdasaran emosional $(M)$ - tekanan peran $(X)$ memiliki nilai minimum sebesar 4,40 yang berarti rata-rata penurunan kecerdasaran emosional $(\mathrm{M})$ - tekanan peran $(X)$ sebesar 4,40 persen, nilai maksimum sebesar 21,12 yang berarti rata-rata peningkatan nilai kecerdasaran emosional $(\mathrm{M})$ - tekanan peran (X) sebesar 21,12 persen, mean sebesar 13,9808 yang berarti rata-rata kontribusi pengaruh variabel kecerdasaran emosional $(\mathrm{M})$ - tekanan peran $(\mathrm{X})$ sebesar 13,9808 persen, dan standar deviasi sebesar 4,10941. Ini berarti bahwa terjadi 
perbedaan nilai kecerdasaran emosional $(\mathrm{M})$ - tekanan peran $(X)$ yang diteliti terhadap nilai rata-ratanya sebesar 4,10941.

Variabel kejenuhan kerja $(\mathrm{Y})$ memiliki nilai minimum sebesar 2,67 yang berarti rata-rata penurunan nilai kejenuhan kerja sebesar 2,67 persen, nilai maksimum sebesar 4,67 yang berarti rata-rata peningkatan nilai kejenuhan kerja sebesar 4,67 persen, mean sebesar 3,8200 yang berarti rata-rata kontribusi nilai kejenuhan kerja sebesar 3,8200 persen, dan standar deviasi sebesar 0,54079. Ini berarti bahwa terjadi perbedaan nilai kejenuhan kerja yang diteliti terhadap nilai rata-ratanya sebesar 0,54079 .

Tabel 4. Rangkuman Hasil Analisis MRA

\begin{tabular}{|c|c|c|c|c|c|c|}
\hline \multirow[b]{2}{*}{ Variabel } & & & \multicolumn{2}{|c|}{ Koefisien Regresi } & \multirow[b]{2}{*}{$\mathrm{t}$} & \multirow[b]{2}{*}{ Sig } \\
\hline & & & B & $\begin{array}{l}\text { Std. } \\
\text { Error }\end{array}$ & & \\
\hline \multicolumn{3}{|l|}{ (constant) } & $-0,943$ & 1,263 & $-0,747$ & 0,459 \\
\hline \multicolumn{3}{|l|}{ Tekanan peran } & 1,145 & 0,388 & 3,000 & 0,004 \\
\hline \multicolumn{3}{|c|}{ Kecerdasan emosional } & 0,982 & 0,396 & 2,477 & 0,017 \\
\hline \multicolumn{3}{|c|}{ Kecerdasan emosional- Tekanan peran | ZXM1| } & $-0,227$ & 0,111 & -2.043 & 0,047 \\
\hline Dependen variabel & : & Kejenuhan kerja & & & & \\
\hline F Statistik & : & 15.653 & & & & \\
\hline $\operatorname{Sig} F$ & : & 0.000 & & & & \\
\hline $\mathrm{R}^{2}$ & : & 0.516 & & & & \\
\hline
\end{tabular}

Sumber: Data Penelitian, 2020

Dari hasil analisis tersebut dapat ditulis persamaan regresi linear berganda sebagai berikut.

$$
\mathrm{Y}=-0,943+1,145 \mathrm{X}+0,982 \mathrm{M} 1-0,227|\mathrm{ZXM}|
$$

Nilai konstanta sebesar $-0,943$ menunjukan bahwa bila tekanan peran $(X)$, kecerdasan emosional $(\mathrm{M})$ sama dengan nol, maka nilai kejenuhan kerja (Y) menuruna sebesar $-0,943$ satuan.

Nilai Koefisien $\beta_{1}$ yang diperoleh sebesar 1,145 menunjukan bahwa interaksi antara variabel tekanan peran dan kejenuhan kerja bersifat positif. Artinya interaksi tekanan peran berpengaruh terhadap kejenuhan kerja auditor pada KAP di Provinsi Bali.

Nilai Koefisien $\beta_{2}$ yang diperoleh sebesar 0,982 menunjukan bahwa interaksi antara variabel kecerdasan emosional dan kejenuhan kerja bersifat positif. Artinya interaksi kecerdasan emosional berpengaruh terhadap kejenuhan kerja auditor pada KAP di Provinsi Bali.

Nilai Koefisien $\beta_{3}$ yang diperoleh sebesar -0,227 menunjukan bahwa interaksi antara variabel kecerdasan emosional dan tekanan peran bersifat negatif. Artinya interaksi kecerdasan emosional memoderasi dengan memperlemah pengaruh tekanan peran terhadap kejenuhan kerja auditor pada KAP di Provinsi Bali.

Hasil uji statistik $F$ pada Tabel 4, menunjukan hasil nilai siginifikansi sebesar 0,000 yang lebih kecil dari tingkat $\alpha=0,05$. Hal ini berarti tekanan peran dan kecerdasan emosional secara bersama berpengaruh signifikan terhadap kejenuhan kerja auditor pada KAP di Provinsi Bali. Hal ini mengindikasikan bahwa model yang digunakan dalam penelitian ini layak dipergunakan. 
Hasil perhitungan uji $\mathrm{t}$ dapat diketahui bahwa nilai koefisien regresi $\mathrm{X}$ adalah sebesar 1,165 dengan tingkat signifikansi sebesar 0,004 lebih kecil dibandingkan dengan taraf nyata $a=0,05$. Hal ini menunjukan bahwa tekanan peran berpengaruh positif dan signifikan terhadap kejenuhan kerja auditor pada KAP di Provinsi Bali.

Hasil perhitungan uji $\mathrm{t}$ dapat diketahui bahwa nilai koefisien regresi $\mathrm{M}$ adalah sebesar 0,982 dengan tingkat signifikansi sebesar 0,017 lebih kecil dibandingkan dengan taraf nyata $a=0,05$. Hal ini menunjukan bahwa kecerdasan emosional berpengaruh positif dan signifikan terhadap kejenuhan kerja auditor pada KAP di Provinsi Bali.

Hasil perhitungan uji $\mathrm{t}$ dapat diketahui bahwa nilai koefisien regresi |ZXM| adalah sebesar -0,227 dengan tingkat signifikansi sebesar 0,047 lebih kecil dibandingkan dengan taraf nyata $a=0,05$. Hal ini menunjukan bahwa kecerdasan emosional seorang auditor memoderasi dengan memperlemah pengaruh tekanan peran terhadap kejenuhan kerja auditor pada KAP di Provinsi Bali, artinya semakin baik kecerdasan emosional seorang auditor akan mampu mengatasi tekanan peran sehingga mampu menurunkan kejenuhan kerja di dalam melaksanakan audit.

Pengujian koefisien determinasi $\left(\mathrm{R}^{2}\right)$ menunjukan bahwa nilai adjusted $\mathrm{R}$ square model 0,516 atau sebesar 51,6 persen artinya sebesar 51,6 persen variasi kejenuhan kerja dapat dijelaskan oleh variasi variabel dalam model tersebut yaitu tekanan peran dan kecerdasan emosional.

Hipotesis pertama menyatakan tekanan peran berpengaruh positif terhadap kejenuhan kerja auditor. Hasil uji parsial menunjukan bahwa tekanan peran berpengaruh positif dan signifikan terhadap kejenuhan kerja auditor pada KAP di Provinsi Bali. Berdasarkan teori peran (role theory) dikemukakan oleh Kevereski et al. (2016) tekanan kerja merupakan multidimensional yang pada dasarnya yaitu tekanan peran, tekanan waktu, tekanan kinerja, konflik peran, dan lain sebagainya sering dihubungkan dengan kejenuhan kerja auditor.

Beberapa penelitian seperti Ermayanti (2017) membuktikan bahwa terdapat pengaruh positif tekanan peran terhadap kejenuhan kerja auditor. Wiryathi et al. (2014) menyatakan tekanan peran memiliki pengaruh terhadap kejenuhan kerja auditor. Platsidou (2010) menyatakan kejenuhan kerja auditor dipengaruhi oleh tekanan peran yang dialami oleh auditor. Dikdik (2008) menyatakan hal yang sama tekanan peran secara positif berpengaruh terhadap kejenuhan kerja auditor.

Hipotesis kedua menyatakan kecerdasan emosional memoderasi pengarug tekanan peran terhadap kejenuhan kerja auditor. Hasil uji parsial menunjukan bahwa kecerdasan emosional memoderasi atau memperlemah pengaruh positif tekanan peran terhadap kejenuhan kerja auditor pada KAP di Provinsi Bali. Teori peran (role theory) memberikan pemahaman kecerdasan emosional berhubungan dengan kemampuan mengontrol dan mengendalikan diri serta bersikap empati. Pengendalian diri berkaitan dengan kemampuan memahami diri sendiri sehingga tidak kehilangan kendali diri yang merugikan diri sendiri untuk menghindari terjadinya tekanan peran yang berkepanjangan, sedangkan empati berkaitan dengan kemampuan memahami orang lain 
sehingga tidak menimbulkan tindakan yang merugikan orang lain yang merasakan kejenuhan kerja (Wiryathi et al., 2014).

Hasil penelitian ini sama dengan penelitian Liman \& Merkusiwati (2017) menyatakan kecerdasan emosional memoderasi dengan memperlemah hubungan tekanan peran terhadap kejenuhan kerja auditor. Wiryathi et al. (2014) membuktikan bahwa kecerdasan emosional secara moderasi dapat mengurangi terjadinya tekanan peran sehingga mampu menurunkan kejenuhan kerja auditor. Avionela \& Fauziah (2016) kejenuhan kerja auditor yang dipengaruhi oleh tekanan peran dapat dihindari dengan moderasi variabel kecerdasan emosional. Samaei et al. (2017) menyatakan hal yang sama pengaruh tekanan peran secara positif terhadap kejenuhan kerja secara moderasi dapat diperlemah oleh kecerdasan emosional.

\section{SIMPULAN}

Berdasarkan pada pembahasan pada bab-bab sebelumnya, maka adapun hal-hal yang dapat disimpulkan yaitu tekanan peran berpengaruh positif signifikan pada kejenuhan kerja auditor pada kantor akuntan publik di Provinsi Bali. Artinya semakin tinggi tekanan peran yang dirasakan seorang auditor maka kejenuhan kerja akan semakin meningkat. Kecerdasan emosional memoderasi pengaruh tekanan peran pada kejenuhan kerja auditor pada kantor akuntan publik di Provinsi Bali. Artinya kecerdasan emosional yang dimiliki oleh seorang auditor menyebabkan terjadinya tekanan peran yang dirasakan auditor sehingga menimbulkan kejenuhan kerja akan semakin meningkat.

Keterbatasan Penelitian ini adalah lokasi penelitian ini hanya di KAP di Provinsi Bali dan hanya meneliti mengenai kejenuhan kerja, sedangkan masih terdapat beberapa lokasi lainnya selain Bali, seperti Jakarta, Surabaya yang lebih luas daripada wilayah Bali. Selain itu penelitian hanya mengunakan teknik analisa moderasi (MRA), sedangkan dapat dikembangkan lagi dengan teknik analisa yang lainnya, seperti: konfirmatori dan SEM analisis dan path analisis. Dan yang terakhir penelitian melibatkan subyek yang terbatas, yakni 48 orang responden, sehingga hasilnya belum dapat digeneralisasikan pada kelompok subyek dengan jumlah besar.

\section{REFERENSI}

Aggarwal, S. (2017). Role of emotional intelligence as a buffer effect in stress management of newly recruited employees. Int. J. Appl. Sci. Manag. International Journal of Applied Sciences and Management, 2(2), 269-282.

Akintayo, D. I. (2010). Job Security, Labour-Management Relations And Perceived Workers` Productivity In Industrial Organizations: Impact Of Technological Innovation. International Business \& Economics Research Journal (IBER), 9(12), 131-140. https:/ / doi.org/10.19030/iber.v9i9.623

Avionela, F., \& Fauziah, N. (2016). Hubungan Antara Kecerdasan Emosi Dengan Burnout Pada Guru Bersertifikasi Di Sma Negeri Kecamatan Bojonegoro. Empati, 5(45), 687-693.

Budiasih, I. G. A. N. (2017). Burnout Pada Auditor Di Kantor Akuntan Publik Provinsi Bali. Jurnal Riset Akuntansi Dan Keuangan, 5(3), 1589-1600. https://doi.org/10.17509/jrak.v5i3.9222 
Dikdik, A. (2008). Pengaruh Role tress Terhadap Perilaku Disfungsional Internal Auditor. Dimensia, 5(1), 41-104.

Erbil, Y. (2016). The Relationship Between Emotional Intelligence and Burnout Levels Among Architecture Students. MEGARON / Yildiz Technical University, Faculty of Architecture E-Journal, 11(4), 491-501. https://doi.org/10.5505/megaron.2016.88319

Ermayanti, D. (2017). Pengaruh Emotional Quotient, Pengalaman Auditor Dan Akuntabilitas Terhadap Kualitas Audit. Eksis: Jurnal Riset Ekonomi Dan Bisnis, 12(2), 178-190.

Gbenro, B. A. (2014). Job burnout among working mothers in Nigeria postconsolidation banks: Effects of work-family conflict and job stress. International Journal of Research Studies in Psychology, 3(5), 27-36. https:// doi.org/10.5861/ijrsp.2014.804

Ghozali, I. (2016). Aplikasi Analisis Multivariate dengan Program IBM SPSS 21 : Update PLS Regresi. Universitas Diponegoro.

Kevereski, L., Kotevska Dimovska, M., \& Ristevski, D. (2016). The influence of the emotional inteligence in protection of the mental health in conditions of a psychosocial stress. International Journal of Cognitive Research in Science, Engineering and Education, 4(1), 17-22. https://doi.org/10.5937/IJCRSEE1601017K

Liman, D. S., \& Merkusiwati, N. K. L. A. (2017). Kecerdasan Emosional Sebagai Pemoderasi Pengaruh Kompetensi Dan Independensi Auditorterhadap Kinerja Auditor. E-Jurnal Akuntansi, 21(1), 562-587.

Murtiasri, E. (2006). Anteseden Dan Konsekuensi Burnout Pada Auditor: Pengembangan Terhadap Role Stress Model. Simposium Nasional Akuntansi IX.

Platsidou, M. (2010). Trait emotional intelligence of greek special education teachers in relation to burnout and job satisfaction. School Psychology International. https://doi.org/10.1177/0143034309360436

Rahayu, L. P. D., \& Widhiyani, N. L. S. (2020). Pengaruh Role Stress Terhadap Perilaku Burnout Auditor Yang Dimoderasi Oleh Emotional Quetient KAP Provinsi Bal. E-Jurnal Akuntansi, 30(2), 334-346. https:// doi.org/10.24843/EJA.2020.v30.i02.p05

Rizkia, P. (2015). Pengaruh Healthy Lifestyle, Role Ambiguity Dan Role Conflict Terhadap Job Satisfaction Dimediasi Oleh Job Burnout Dan Psychological Well-Being. Simposium Nasional Akuntansi XVIII Medan, 1-30.

Samaei, S. E., Khosravi, Y., Heravizadeh, O., Ahangar, H. G., Pourshariati, F., \& Amrollahi, M. (2017). The Effect of Emotional Intelligence and Job Stress on Burnout: A Structural Equation Model among Hospital Nurses. International Journal of Occupational Hygiene, 9(2), 52-59.

Sari, N. E. R., \& Suryanawa, I. (2016). Konflik Peran, Ketidakjelasan Peran, Dan Kelebihan Peran Terhadap Kinerja Auditor Dengan Tekanan Waktu Sebagai Pemoderasi. E-Jurnal Akuntansi, 15(2), 1392-1421.

Shukla, A., \& Srivastava, R. (2016). Examining the effect of emotional intelligence on socio-demographic variable and job stress among retail employees. Cogent Business and Management, 3(1). https:/ / doi.org/10.1080/23311975.2016.1201905 
Sugiyono. (2017). Metode Penelitian Bisnis. CV. Alfabeta.

Vlachou, D. E. M. (2016). The Relationship between Burnout Syndrome and Emotional Intelligence in Healthcare Professionals. ICUS and Nursing Web Journal, 1-9.

Wiryathi, N. M., Rasmini, N. K., \& Wirakusuma, M. G. (2014). Pengaruh Role Stressors pada Burnout Auditor dengan Kecerdasan Emosional sebagai Variabel Pemoderasi. E-Jurnal Ekonomi Dan Bisnis Universitas Udayana, 5(3), 227-244. 